\title{
PEMBANGUNAN PARIWISATA GLOBAL DI BALI
}

\author{
Oleh \\ I Nengah wijaya ${ }^{1)}$ \& I Nyoman Kanca ${ }^{2)}$ \\ ${ }^{1,2}$ Politiknik Negeri Bali
}

\begin{abstract}
Global Tourism Development is a tourism development that includes tourist areas that are in areas that have a strong and attractive attraction to be developed equally and equal to the existing tourist attraction in Bali that has advanced first, and can improve the development and growth of tourism in Bali can also be used to offset the rate of growth and the spread of the population, so that the level of prosperity can be maintained. The development of tourism in Bali so far we know only concentrated on certain areas and regions that cause negative impacts and saturation because it always uses nature and environment, culture in excess, and will affect the level of comfort and security for tourists who vacation in Bali, tourists do not want more long stay because it is not feel the comfort. Every product generally includes also paririsisata products also experience life cycle that is the period of introduction, growth, maturity, and old age. The period of maturity of pruduk is becoming known and favored by consumers where the sale of the product can reach its peak, therefore industry must be able to maintain the product in fulfilling the consumer's taste, then in the old age, this is the last period of product life cycle marked by the decrease of product sales, sales of technological advances, and changing consumer tastes. By using the right marketing strategy to increase sales of tourism products through the media of perikalan, it can increase the visit and length of stay of tourists who come to Bali.
\end{abstract}

Keywords: Development, Tourism \& Global

\section{PENDAHUALUAN}

Pembangunan Pariwisata adalah sebagai penggerak dalam pembangunan perekonomian secara umum atau secara makro di Bali dan memiliki peran penting di banyak negara termasuk di Indonesia, karena pariwisata adalah salah satu sektor produktif yang dapat memacu pertumbuhan perekonomian suatu negara seperti menciptakan lapangan kerja, dan memperluas kesempatan beruasaha baik berupa penyediaan sarana akomodsi, restoran, souvenir shop, maupun penyedia transportasi. Sebagai salah satu daerah tujuan pariwisata terkenal di Dunia, Bali memiliki banyak daya tarik alam maupun budaya. Sumber daya alam maupun budaya Bali tidak hanya menarik bagi wisatawan domestik namun juga wisatawan macanegara, dapat dilihat dengan terus meningkatnya jumlah kunjungan wisatawan mancanegara datang ke Bali setiap tahunnya.

Potensi wisata yang menjadi daya tariknya antara lain adalah budaya, panorama alam yang indah, hutan alam, dan peninggalan sejarah yang http://ejurnal.binawakya.or.id/index.php/MBI asri yang sangat menarik bagi wisman untuk melakukan trekking, rafting, dan caving. Selain itu, berbagai jenis flora dan fauna yang diantaranya tergolong langka, merupakan daya tarik tersendiri untuk menunjang kegiatan wisata, khususnya ekowisata di Bali.

Bali saat ini telah menjadi kawasan wisata yang terkenal sampai ke mancanegara. Beberapa fasilitas akomodasi berkembang pesat terutama sebelum terjadinya krisis ekonomi. Keberadaan fasilitas akomodasi sangat diperlukan untuk memberikan kepuasan para wisatawan. Disamping itu, masyarakat sudah terbiasa bergaul dengan para wisatawan Internasional dan terlibat langsung dalam kegiatan wisata merupakan kekuatan lebih yang sangat menunjang kegiatan wisata. Beberapa contoh keterlibatan masyarakat tersebut antara lain adalah ikut sebagai pemandu wisata, pedagang souvenir, pedagang makanan, karyawan hotel.

Dunia bisnis perhotelan juga berkembang seiring dengan meningkatnya jumlah kunjungan wisatawan baik lokal maupun mancanegara.

Vol.13 No.10 Mei 2019

\section{Open Journal Systems}


Tamu-tamu lokal pada umumnya berlibur diakhir pekan, mereka tinggal untuk satu sampai beberapa hari. Keberadaan tamu lokal yang datang pada akhir pekan membuat kondisi distinasi wisata terus hidup. Dilihat dari motifasi kunjungan tamu, baik lokal maupun manca negara pada umumnya ingin menikmati keasrian budaya, dan alam. Oleh karena itu, orientasi bisnis perhotelan harus menyesuaikan diri dengan selera konsumen yang menikmati wisata alam dan budaya. Para pengusaha hotel mencoba menawarkan jasa penginapan yang sedikit berbeda dengan bisnis penginapan lainnya. Letak perbedaanya ada pada pola pelayanan dan fasilitas yang disediakan.

Pasar bebas yang mengakibatkan dunia perdagangan menjadikan persaingan promosi yang lebih seru, karena banyaknya jenis produk yang ditawarkan. Berbagai jenis produk yang ditawarkan sangat berhati-hati dalam mengisi dicelah-celah bisnis melalui promosi. Mengatur strategi pemasaran melalui promosi antar produsen agar produknya meningkat dan jangkauan pasar lebih luas merupakan langkah yang tepat yang harus dilakukan yaitu salah satunya dengan promosi melalui media periklanan.

Persaingan antar produk di pasaran mendorong produsen gencar untuk berpromosi yang dapat menarik perhatian konsumen. Promosi dapat dilakukan melalui berbagai cara, antara lain; melalui promosi penjualan, publisitas umum, penjualan pribadi, dan periklanan. Promosi melalui media periklanan sangatlah efisien karena menggunakan biaya rendah dan mempunyai daya bujuk (persuasif) yang kuat. Promosi melalui periklanan sangatlah efektif karena dapat memberikan informasi yang jelas terhadap produk pada segmen tertentu.

$$
\text { Pembangunan }
$$

pariwisata

berkelanjutan bukanlah suatu upaya untuk menghentikan perkembangan lebih lanjut dalam masyarakat, melainkan suatu pembangunan terkendali yang mempertimbangkan generasi lalu dan generasi yang akan datang. Jika pertimbangan budaya dari sudut pandang pembangunan berkelanjutan, maka ada tiga unsur

\section{Vol.13 No.10 Mei 2019}

yang harus diperhatikan yaitu : kualitas pengalaman yang diperoleh wisatawan, kualitas sumber daya yang dapat dipasarkan, dan kualitas kehidupan manusia atau masyarakat di sekitar yang mempunyai sumber daya (Ardika, 2003:30).

Berdasarkan konsep tersebut, sasaran pariwisata kerkelanjutan adalah keseimbangan antara masa lampau dan masa depan. Dalam usaha ini perlu dihasilkan suatu perlindungan dan pengalaman yang lebih baik bagi para pengunjung, dan meningkatkan kondisi sosial ekonomi masyarakat setempat. Pengalaman menujukkan bahwa semakin baik kondisi kehidupan masyarakat objek wisata maka semakin baik pelestarian budayanya (Ardika, 2003:34).

Bali adalah suatu daerah tujuan wisata (DTW) di Indonesia yang memiliki banyak potensi, selain panorama dan keindahan alam, budaya, dan iklim yang sejuk dibeberapa daerah, Bali juga memiliki beragam adat istiadat, bahasa, dan kesenian, serta tempat-tempat maupun bangunan yang bersejarah (Departemen Kebudayaan dan Pariwisata, $2006: 3$ ).

Pembangunan pariwisata global, berarti pembangunan pariwisata yang mengikut sertakan kawasan wisata yang berada di daerah-daerah yang mempunyai daya tarik yang kuat untuk dikembangkan secara merata dan setara dengan daya tarik wisata yang ada di Bali yang sudah maju, sehingga dapat meningkatkan perkembangan dan pertumbuhan pariwisata di Bali dan dapat digunakan mengimbangi lajunya pertumbuhan dan penyebaran penduduk, sehingga tingkat kemakmuran bisa dipertahankan. Pembangunan pariwisata di Bali selama ini kita tahu hanya terpusat pada kawasan dan daerah yang menimbulkan dampak negatif dan kejenuhan karena selalu menggunakan alam serta lingkungan, budaya secara berlebihan, dan akan mempengaruhi tingkat kenyamanan dan keamanan bagi wisatawan yang berlibur ke Bali, sehingga wisatawan tidak mau lebih lama tinggal karena sudah tidak merasakan kenyamanan.

Industri pariwisata sebagai invisible export, dimana menghasilkan devisa tanpa mengekspor http://ejurnal.binawakya.or.id/index.php/MBI 
barang-barang ke luar negeri. Ada kecendrungan semakin banyak jumlah wisatawan, lebih banyak tinggal, dan lebih besar pengeluaran rata-rata semakin besar devisa yang diterima, sehingga perlu diusahakan agar lebih banyak wisatawan yang datang, lebih lama tinggal, dan lebih setabil nilai mata uang rupiah terhadap Dolar Amerika.

Dari latar belakang masalah yang telah diuraikan sebelumnya, maka dapat dikemukakan pokok permasalahan yaitu : Bagaimana Pembangunan Pariwisata Global di Bali

Berdasarkan Pokok permasalan diatas, maka tujuanya adalah : Untuk nengetahui Pembangunan Pariwisata Global di Bali. Adapun manfaat yang diperoleh dari penelitian ini antara lain yaitu : Untuk dapat memberikan pemahaman, khususnya mengenai Pembangunan Pariwisata Global di Bali, dan sebagai bahan perbandingan bagi mereka yang ingin mengetahui mengenai Pembangunan Pariwisata Global di Bali.

Pengertian Global sesuai dengan kamus besar bahasa Indonesia adalah dilihat dari kata sifat yaitu artinya secara umum dan keseluruhan, secara garis besar, yang meliputi seluruh dunia. Sementara kata mengglobal merupakan bentuk kata kerjanya yang berarti mendunia atau meluas (Pengertian menurut para ahkli dan definisi 31 Mei 2016, Google, Rabu 25 April 2018 jam $14^{15}$ pengertian menurut paraakhli.net).

Melihat pengertian di atas global (dalam hal ini), maka dapat diartikan bahwa kemampuan atau mempunyai daya tarik, yang bisa mengikut sertakan dalam hal pembangunan dan pengembangan dalam bidang pariwisata secara luas dan menyeluruh, sehingga dapat meningkatkan jumlah dan lama tinggal wisatawan yang berkunjung di suatu distinasi.

Damayanti (2015), dalam penelitiannya tentang Strategi pembangunan pulau Nusa Penida sebagai kawasan pariwisata berkelanjutan dalam Jurnal Soshum, mengkaji dengan analisis Swot untuk memperoleh Strategi yang sesuai, dengan melakukan identikasi terhadap faktor strategis internal dan faktor strategis eksternal yang mempengaruhi pembangunan pulau Nusa Penida. Hasil analisis menunjukkan ada empat set strategi http://ejurnal.binawakya.or.id/index.php/MBI alternatif yang dapat dirumuskan yaitu : meningkatkan promosi, melakukan penataan dan melestarikan lingkungan serta melibatkan masyarakat dalam pengembangan pariwisata, mengembangkan daya tarik wisata yang lebih bervariasi serta fasilitas kepariwisataan dan fasilitas umum, dan membentuk badan pengelola dan meningkatkan sumber daya manusia.

Wijaya (2016), dalam penelitiannya tentang Studi Pendapatan Usaha penyeberangan 'Boat' antara Nusa Penida-Sanur untuk menunjang kawasan wisata Nusa Penida, mengkaji kebutuhan akan transportasi yang aman dan nyaman untuk menunjang kawasan wisata Nusa Penida menjadi sangat diperlukan, karena kunjungan wisatawan cenderung mengalami peningkatan serta dapat memberikan lapangan pekerjaan dan akan meningkatkan pendapatan masyarakat. Secara prinsip ke dua penelitian tersebut di atas sejalan dengan penelitian yang dilaksanakan ini, yaitu variabel yang digunakan sama-sama menguatkan dan meingkatkan daya tarik wisata untuk dapat menangkap peluang atau potensi, sehingga akhirnya dapat meingkatkan pendapatan masyarakat pada umumnya.

Istilah pariwisata berhubungan erat dengan pengertian perjalanan wisata, yaitu sebagai suatu perubahan tempat tinggal sementara seseorang diluar tempat tinggalnya karena suatu alasan dan bukan untuk melakukan kegiatan yang menghasilkan atau mencari nafkah. Orang yang melakukan perjalanan disebut traveler, sedangkan orang melakukan perjalan untuk tujuan wisata disebut tourist. Pariwisata pada hakekatnya adalah merupakan perjalanan dari sutu tempat ke tempat lain, bersifat sementara dilakukan perseorangan maupun kelompok, sebagai usaha mencari keseimbangan atau keserasian dan kebahagian dalam lingkungan hidup di dalam deminsi sosial, budaya, alam dan ilmu (Ospilane, 1997).

Menurut Yoeti, (1996) pariwisata adalah suatu perjalanan yang dilakukan untuk sementara waktu, yang diselenggarakan dari suatu tempat lain, dengan maksud bukan untuk mencari nafkah di tempat yang dikunjungi, tetapi semata-mata

Vol.13 No.10 Mei 2019 
untuk menikmati perjalanan hidup guna bertamasya dan berkreasi untuk memenuhi keinginan yang beraneka ragam.

Undang-undang No. 5 tahun 1984 tentang perindustrian memberikan pengertian industri sebagai kegiatan ekonomi yang mengolah bahan mentah, bahan baku, bahan setengah jadi, dan barang jadi menjadi barang dengan nilai yang lebih tinggi untuk penggunaannya, termasuk kegiatan rancang bangun untuk perekayasaan industri. Istilah industri pariwisata atau sektor pariwisata, bukan merupakan suatu sektor ekonomi tertentu, dan bukan merupakan cabang produksi tertentu. Adapun barang dan jasa yang diperhitungkan dalam pariwisata berasal dari beberapa sektor, dan ini memenuhi permintaan wisatawan asing maupun dalam negeri (United Nations Conference on Trade and Development dalam Erawan, 1994 : 4).

Selanjutnya berdasarkan penjelasan tersebut maka industri-industri yang dianggap termasuk industri pariwisata adalah : Akomodasi; Agen perjalanan; Restoran dan Cafetaria; Perusahaan angkutan, dan lain-lainnya.

Faktor lama tinggal merupakan salah satu faktor yang menentukan besar atau kecilnya devisa yang diterima untuk negara-negara yang mengandalkan devisa dari industri pariwisata. Secara teoritis, semakin lama seseorang wisatawan tinggal disuatu Daerah Tujuan Wisata (DWT), semakin banyak uang yang dibelanjakannya di daerah tersebut. Paling sedikit untuk keperluan makan dan minum serta akomodasi hotel selama tinggal disana (Yoeti, 1996 :124)

Di Indonesia objek dan atraksi wisata mempunyai perbedaan. Semua daya tarik wisatawan yang bersumber pada alam seperti pemandangan alam dan lain-lain sering disebut sebagai objek wisata. Sedangkan atraksi wisata adalah daya tarik wisata yang apabila ingin dilihat harus dipersiapkan terlebih dahulu oleh orang. Biasanya berwujud peristiwa kejadian, baik yang terjadi secara periodik ataupun sekali saja, baik yang besifat tradisional ataupun yang tetap telah dilembagakan dalam kehidupan masyarakat modern yang mempunyai daya Vol.13 No.10 Mei 2019 positif pada para wisatawan. Seperti pertunjukan kesenian, kebudayaan dan lain-lain. Lain halnya di luar negeri dimana antara objek wisata dan atraksi wisata tidak dibedakan mereka semuanya menyebutnya dengan tourist attraction. Mengenai pengertian distinasi wisata dapat kita lihat beberapa sumber acuan diantaranya :

1. SK Menparpostel No. KM 98/PW102/MPT-87

2. Objek wisata adalah tempat atau keadaan alam yang memiliki sumber daya wisata yang dibangun dan dikembangkan sehingga menjadi daya tarik dan diusahakan sebagai tempat yang dikunjungi oleh wisatawan. Seorang wisatawan yang datang berkunjung kesuatu daerah objek wisata dengan alasan dan tujuan tertentu demi mencapai kepuasan dan mencari mamfaat dari kunjungannya. Mamfaat dan kepuasan itu ditentukan oleh dua faktor yang saling berkaitan, yaitu tourism resource sama dengan objek dan atraksi wisata Objek, dan atraksi wisata adalah segala sesuatu yang terdapat di daerah tujuan wisata yang merupakan daya tarik agar orangorang mau datang berkunjung ketempat tersebut.

3. Yoeti (1996:121) menjelaskan bahwa terdapat perbedaan tentang makna objek wisata dan atraksi wisata. Kita hanya akan menyatakan itu objek wisata bila untuk melihat objek tersebut tidak diperlukan persiapan terlebih dahulu, dengan kata lain kita dapat melihatnya secara langsung tampa bantuan orang.

\section{METODE PENELITIAN}

Metode pengambilan sampel yang digunakan adalah dengan menggunakan metoda purposive sampling dengan pertimbangan bahwa Provinsi Bali mempunyai potensi yang sangat besar dalam perencanaan dan pengembangan pariwisata yang berkelanjutan. Penggunaan data berdasarkan sifat data yaitu data kualitatif dan kuantitatif saja, dan suber datanya adalah data skender, dan observasi lapangan dilaksanakan http://ejurnal.binawakya.or.id/index.php/MBI 
untuk pengumpulan data dan informasi dari instansi tingkat provinsi, kabupaten, dan kecamatan yang berkaitan dengan masalah.

\section{HASIL DAN PEMPEMBAHASAN}

Sejak dilakukan langkah-langkah untuk pengembangan kebudayaan dan pariwisata di negara kita, maka kegiatan-kegiatan terencana dan terprogram yang dilakukan, pada hakekatnya memang bertujuan untuk berkelanjutan. Khusus dibidang pariwisata yang dimaksud pembangunan pariwisata berkelanjutan pada intinya berkaitan dengan usaha menjamin agar sumber daya alam, sosial dan budaya yang kita manfaatkan untuk pembangunan pariwisata dalam generasi ini dapat dilestarikan untuk generasi mendatang (Ardika, $2002: 23$ ) .

Kebanyakan pemerintah negara Asia menghadapi problem pembangunan yang berat, jumlah penduduk mulai meningkat dengan kebutuhan-kebutuhan senantiasa, dan kegelisahan sosial yang mengancam jika segala sesuatu tidak dikerjakan untuk meringankan beban. Tourisme masal atau mass tourism akan membawa banyak mata uang asing yang diperlukan untuk usaha-usaha pembangunan ekonomi. Dengan demikian ekonomi akan menerima dorongan baru yaitu tercipatanya kesempatan kerja baru, produk-produk kerajinan lokal dan para seniman akan dibutuhkan dipasaran, tumbuhnya industri kecil dan rumahrumah penginapan, dan pendapatan per kapita dan GNP akan bereaksi secara positif sebagai tantangan terhadap semua pembangunan pariwisata.

Berlakukannya UU NO 22 Tahun1999 dan UU NO 25 Tahun 1999 tentang pemerintah daerah dan perimbangan keuangan antara pusat dan daerah. Daerah dituntut untuk selalu berupaya semaksimal mungkin dalam meningkatkan pendapatan asli daerah. Hal ini bisa di lakukan dengan memanfaatkan potensipotensi yang ada, salah satunya adalah potensi pariwisata. Dengan otonomi daerah tesebut pemerintah pusat memberikan wewenang kepada pemerintah daerah secara penuh dalam mengelola dan memanfaatkan potensi pariwisata http://ejurnal.binawakya.or.id/index.php/MBI yang ada di daerahnya. Serta menetapkan dan mengusahakan sendiri dalam melaksanakan pengembangannya.

Provinsi Bali memiliki potensi wisata yang begitu banyak dan beragam, baik itu wisata alam, wisata sejarah, dan budaya. Hal ini tentu sangat membantu kepariwisataan di daerah khususnya dalam hal perekonomian penduduk setempat. Pariwisata alternatif yang bisa dikembangkan di provinsi Bali berdasarkan potesi wisata yang ada yaitu : wisata alam, wisata sejarah, dan wisata budaya.

Pariwisata masa kini adalah merupakan produk dari kemajuan sosial, dengan pengelolaan yang sehat serta pengertian yang tepat, maka akan bisa merupakan wahana yang baik dalam mencapai kemajuan sosial budaya, dan perbaikan perekonomian. Seperti pembangunan kawasan pariwisata Nusa Penida, di mana pembangunannya berjalan dengan sendiri sekarang tidak terduga menjadi distinasi pariwisata yang sangat diminati, karena mempunyai daya tarik yang sangat kuat terutama pariwisata spiritualnya, bahkan bisa disejajarkan dengan distinasi wisata kawasan pariwisata lain yang telah maju di Bali.

Dampak pariwisata terhadap kondisi ekonomi mayarakat lokal dapat dikatagorikan menjadi beberapa kelompok, Cohen (dalam Pitana, 2005:109) yaitu :

1. Dampak terhadap penerimaan Devisa yaitu: pariwisata telah memberikan devisa yang cukup besar bagi berbagai negara, dan bagi beberapa daerah, pariwisata telah menjadi penghasil devisa terbesar. Peranan pariwisata juga sangat besar bagi Indonesia. Devisa yang diterima secara berturut-turut pada tahun 2002 sebesar U\$\$ 4.496 milyard, dan tahun 2003 sebesar U\$ 4.037 milyard Nirwandar (dalam Pitana, 2005:111).

2. Dampak terhadap pendapatan masyarakat yaitu : dari segi pendapatan masyarakat, dapat diharapkan mampu menghasilkan angka berganda atau multiplier effect yang tingi yang melebihi angka pengganda

Vol.13 No.10 Mei 2019

\section{Open Journal Systems}


berbagai kegiatan ekonomi lainnya. Erawan (Pitana, 2005:110)

3. Dampak terhadap kesempatan kerja yaitu : dari segi ketenaga kerjaan pada tahun 1995 pariwisata menyerap 34,14\% dari jumlah tenaga kerja di Bali, dan tahun 1998 naik mencapai 38 \% (Pitana, $2005: 113$ )

4. Dampak terhadap harga-harga barang pada umumnya yaitu : dari segi harga-harga, juga mengalami kenaikan kerena diikuti oleh pendapatan masyarakat, sehingga daya beli masyarakat ikut naik. munculnya neo kolonialisme atau neo imprialisme.

10. Terjadinya kebocoran ekonomi atau economic leakage yaitu terjadi begitu besar, terutama resor-resor yang sifatnya tertutup yang didominasi oleh modal asing. Mengalirnya manfaat ekonomi dari negara berkembang ke negara maju akan menyebabkan ketimpangan dalam pemerataan pendapatan.

Dampak pembanguna pariwisata di atas ini termasuk pembangunan pariwisata dibidang ekonomi

5. Dampak terhadap distribusi manfaat atauyang sifatnya negatif atau merusak, sehingga akan keuntungan yaitu : dari segi distribusimenjadi ancaman terhadap pembangunan pariwisata manfaat atau keuntungan , di manberkelanjutan, dan pariwisata di Bali akan menjadi didistribusikan ke berbagai sektor yaitutidak normal lagi.

hotel dan restoran, dan lain-lainnya. Panduan rencana tata ruang kabupaten dan

6. Dampak terhadap pemilikan, dan kontroprovinsi lebih dominan pada perencanaan fisik yaitu : dari segi pemilikan, dan kontrol, dilingkungan daratan, sedangkan fisik lingkungan mana pemilik dari pada modal yang besakawasan pesisir dan lautan belum banyak terungkap kebanyakan dimiliki pemilik asing,(Raka Dalem,2007:171). Banyaknya potensi-potensi sehingga terjadi kebocoran misalnya hoteperekonomian di pesisir dan lautan yang dan restoran. berkembang, munculnya konplik-komplik

7. Dampak terhadap pembangunan padapemanfaatan ruang kawasan pesisir, maka pada tahun umumnya yaitu : dari segi pembangunan2002 Dirjen Pesisir dan pulau-pulau kecil, konsep pada umumnya, sudah berjalan sesuatersebut berasaskan (Raka Dalam, 2007 : 171) yaitu : dengan tata ruang provinsi, dan diamanæa) keadilan bagi semua kepentingan masyarakat; b) masing-masing kabupaten harus bisterpadu, yang merupakan satu kesatuan berbagai menyesuaikan tata ruangnya masing pemanfaatan ruang, menyeluruh, pertimbangan masing terhadap tata ruang yang lebihwaktu, modal, optimasi, daya dukung lingkungan, tinggi.

dan geografik; c) berdaya guna dan berhasil guna

8. Dampak terhadap pendapatan pemerintahsesuai dengan potensi ruang; d) serasi, selaras, dan yaitu : dari segi pendapatan pemerintah,seimbang, pemanfaatan ruang; e) keberlanjutan, yang PHR merupakan sumber Pad yang sangatmenjamin kelestarian kemampuan daya dukung besar peranannya dalam pembangunansumber alam.

Bali pada tahun 1999/2000, jumlah PHR yang dihasilkan seluruh kabupaten/kota dPENUTUP Bali mencapai 299,483 milyard rupiah, darKesimpulan tahun 2001 sebesar 421,853 milyard rupiah Pembangunan pariwisata global harus (Pitana, 2005:113) mengikut sertakan distinasi yang sudah ada diseluruh

9. Pembangunan pariwisata akanBali, yang mempunyai daya tarik yang kuat untuk menyebabkan semakin buruknyadibangun serta dikembangkan, disejajarkan dengan pendapatan antar kelompokdistinasi yang sudah maju dan terkenal. Sebagai memburuknya ketimpangan antar daerahkordinasinya adalah pada tingkat provinsi. Distinasi hilangnya kontrol masyarakat lokakang ada di daerah-daerah yang diikut sertakan dapat terhadap sumber daya ekonomimengurangi masalah global yang dihadapi di Bali, seperti masalah budaya, kemacetan, komplik 
berkepanjangan, sehingga dengan demikian bisa meningkatkan lama tinggal disamping jumlah kunjungan wisatawan ke Bali.

Saran

Pembangunan Pariwisata global perlu mendapat perhatian dalam pengembangan pariwisata di Bali baik pemerintah, masyarakat, dan investor, terutama dalam pembangunan kawasan pariwisata 10 harus memperhatikan pemerataan di daerah-darah jangan hanya terpusat di daerah, dan kawasan tertentu, karena dapat menimbulkan masalah yang[11] Suparmoko, 1991, Pengantar Ekonomi sangat komplek seperti masalah kebudayan, Makro, Penerbit BPFE - Yogyakarta transportasi, dan penduduk, sehingga Bali[12] Wijaya, I. N., Sukmawati, N. M. R., \& kemungkinan bisa menjadi tujuan pariwista tidak normal lagi.

\section{DAFTAR PUSTAKA}

[1] Ardika, I Wayan, 2007, Pusaka dan Budaya Pariwisata. Cetakan Pertama, Penerbit Pustaka Larasan, Denpasar.

[2] Ardika, I Wayan, 2003. Pariwisata Budaya Berkelanjutan. Cetakan Pertama, Penerbit Program Studi (2) Kajian Pariwisata Program Paska Sarjana Universitas Udayana, Denpasar.

[3] Damayanti, I. A. K. W., Wijaya, I. N., \& Kanca, I. N. K. (2017). STRATEGI PENGEMBANGAN PULAU NUSA PENIDA SEBAGAI KAWASAN PARIWISATA YANG BERKELANJUTAN. Soshum: Jurnal Sosial dan Humaniora, 5 (2 Juli), 136

[4] Pitana, I Gede, 2005, Sosiologi Pariwisata, Penerbit Andi Yogyakarta.

[5] Pujastawa, I.B.G., Dkk., 2005, Pariwisata Terpadu Alternatif Model Pengembangan Pariwisata Bali Tengah.

[6] Raka Dalem, A.A.G., Dkk. 2007, Kearifan Lokal dalam Pengelolaan Lingkungan Hidup, UPT Penerbit Universitas Udayana.

[7] Sugiarto, Endar, Ir, MM. 2001, Pengantar Akomodasi dan Reatoran, Penerbit Gramedia Utama Yakarta.

[8] Suryawan,Wiranatha, Agung, Dkk. 2008, Analisis Kebutuhan Akomodasi, dan Transportasi Pariwisata di Bali Cetakan pertama, Penerbit Pusat Penelitian http://ejurnal.binawakya.or.id/index.php/MBI
Kebudayaan dan Kepariwisataan Universitas Udayana.

[9] Suryawan,Wiranatha, Agung, Dkk. 2009, Karakteristik Wisatawan Nusantara ke Bali Cetakan pertama, Percetakan Swata Nulus. Penerbit Pusat Penelitian Kebudayaan dan Kepariwisataan Universitas Udayana.

Spillane, James J, 1990, Ekonomi Pariwisata, Cetakan ketiga, Penerbit Kanisius Jogyakarta.

Kanca, I. N (2017). STUDI PENDAPATAN USAHA PENYEBERANGAN 'BOAT'ANTARA NUSA PENIDASANUR UNTUK MENUNJANG KAWASAN WISATA NUSA PENIDA. Soshum: Jurnal Sosial dan Humaniora, 6(1 maret), 78.

[13] Wirawan, Nata I.G.P. 2001, Satistik 2, untuk Ekonomi dan Bisnis Edisi Kedua, Penerbit Keraras Emas, Denpasar. 
HALAMAN INI SENGAJA DIKOSONGKAN 